\title{
DECENTRALISATION AND LOCAL SELF-GOVERNMENT DEVELOPMENT AS KEY ISSUES OF PUBLIC ADMINISTRATION REFORM IN UKRAINE: CURRENT STATE AND NEW OBJECTIVES TO BE ATTENDED
}

\author{
Denys ZAPYSNYY ${ }^{1}$ \\ International Foundation "Prostir (Space)", Ukraine
}

\begin{abstract}
This article presents the status and the main objectives of the decentralisation process and local self-government development in Ukraine. Decentralisation is analyzed as an integrated part of wider public administration reform. A well-functioning public administration is necessary for democratic governance. It also directly impacts upon governments' ability to provide public (administrative and municipal) services and to foster competitiveness and growth. Public administration reform should lead to enhanced transparency, accountability and effectiveness and ensure a greater focus on the needs of citizens and business. On the basis the analysis of the Ukrainian legislation, the best national and international practices, the proposals and the recommendations concerning possible ways of further local self-government development, in particular in the framework of the European integration policy implementation, are highlighted.
\end{abstract}

Key words: decentralisation, public administration reform, local development, local self-government, modernization, European integration, administrative (municipal) services delivering.

JEL Classification: H83, F63, F15

\section{Description of the problem}

Today, Ukraine is facing an urgent need to implement large-scale decentralisation reform. Decentralisation in Ukraine can be viewed as a part of a wider public administration reform, which requires re-distribution of tasks, competences, and resources at central, regional, and local levels. In particular, this means the transfer of wider responsibilities, competencies, and resources from the state to the local self-government (LSG) authorities, in line with the SIGMA/OECD revised Principles of Public Administration, provisions of the European Charter of Local Self-Government as well as the Council of Europe Strategy for Innovation and Good Governance on Local Level and its 12 Principles for Good Governance on Local Level.

Ukraine slowed down the decentralisation during V. Yanukovych's period (February 2010 - February 2014) and was requested to equip local authorities with real competence in the substantial share of public affairs; to address a too high territorial fragmentation and to reinforce the financial autonomy of local authorities. After "Euromaidan" and V. Yanukovych's departure the new Ukrainian Government and the democratic parliamentary coalition in the Verkhovna Rada proclaimed the decentralisation reform as a key priority of their political agenda.

Corresponding author:

${ }^{1}$ President of the International Foundation "Prostir (Space)".
Better policy planning and co-ordination, sound administrative procedures and improved public financial management are of fundamental importance for the functioning of the local self-government system and for implementing the decentralisation reform required for integration with the EU. Ukraine has to increase its efforts to improve its municipal administration on the basis of the relevant national strategy. A strong political commitment is also needed to steer the decentralisation reform process.

\section{Analysis of the last researches and publications}

During last period Ukraine paid a high attention was paid to issues of the local self-government development. Thus, we could point out the following researchers and scientists who devoted their works to this issue: O. Amosov, V. Bakumenko, M. Kanavets, Y. Kovbasiuk, I. Koliushko, V. Kuybida, N. Nyjnyk, M. Pukhtynskiy, O. Rudenko, T. Pakhomova, O. Povajniy, O. Rudenko, S. Serioguin, A. Tkachuk, V. Tolkovanov, V. Udovychenko and others. At the same time, the new stage of the public administration reform which was started in 2014 will require additional attention and researches concerning the issues of the decentralization and local self-government modernisation. 
Objective of the article. The main objective of this article is to present the current state of the decentralization as an important part of the public administration reform in Ukraine as well as and to highlight the main perspectives of its further implementation.

\section{Presentation of the main content}

The development of local democracy in Ukraine is closely monitored by many international institutions, in particular by the European Union, the Council of Europe and its Congress of Local and Regional Authorities. Thus, the CoE Congress carried out monitoring visits to Ukraine and prepared the important recommendations in the field of decentralisation and LSG development. The European Union supports democratic changes in Ukraine by several activities, with focus on promoting implementation of the SIGMA/OECD revised Principles of Public Administration (reliability and predictability openness and transparency, accountability, efficiency and effectiveness), including through Conference of Regional and Local Authorities for the Eastern Partnership (CORLEAP) which is the EU platform that offers an opportunity to discuss the contribution by cities and regions in the development of the Eastern Partnership.

The World Bank is mainly involved in public finance reforms (for example implementation of medium term performance based budgeting). Initiative on Fiscal Decentralisation was formulated in 2012 by the Sub-group for Local Government and Public Administration Reform of the Civil Society Forum which drafted a short assessment of fiscal decentralisation efforts in EaP Countries (as of 2012) and a set of policy recommendations.

The Article 2 of the European Charter of Local SelfGovernment stipulates that the principle of local selfgovernment shall be recognised in the domestic legislation, and where practicable in the constitution. In this regard, the ECLSG creates itself an excellent benchmark for measuring the level and the scope of the decentralisation in the countries that have already signed and ratified this main European legal instrument in the field of LSG (European Charter of Local Self-Government).

In this context, it has to be noted that Ukraine signed the European Charter of Local Self-Government on 6 November 1996 and ratified it in 1997, without any reservations, with entry into force on 1st January 1998. Ukraine signed in 2011 and ratified in 2014 the Additional Protocol to the European Charter of Local SelfGovernment on the right to participate in the affairs of a local authority.

The Constitution of Ukraine (1996) and the 1997 Law on Local Self-Government are based on a distinction between "local communities" (hromada - citizens of village, town, city) and "administrative and territorial units”. In 2014 11,520 local councils represented 27,210 villages and settlements; around 200 villages and towns were integrated into 64 city councils of regional (oblast) significance and about 1,000 were integrated into city councils of district (rayon) and republic significance. The Constitution of Ukraine defines 24 oblasts as well as the Autonomous Republic of Crimea, the cities Kyiv and Sevastopol which have a special status. The status of the city of Kyiv is regulated by the Law on the Capital of Ukraine the Hero-city Kyiv which was adopted in 1999. The city is divided into 10 districts (rayons) and its population is about 2.63 million inhabitants (Encyclopedia of Public Administration in 8 tomes, 2011).

Administrative and territorial division of Ukraine is characterized by a number of problems. Ukraine with its nearly 28,000 municipalities is one of the most fragmented countries in Europe (Kuybida, Tkachuk, Tolkovanov, 2010). This fragmentation leads to decreasing financial autonomy, low quality of public services in small municipalities, lack of possibility to manage issues of local significance of municipalities etc. As a result residents of small communities do not have access to high-quality services in their communities and have to address their needs to district/city authorities or higher.

There is lack of clear differentiation between concepts of local communities (hromada) as a social term and as a part of administrative and territorial division of the state. According to Article 140 of the Constitution a local community (hromada) is defined as "residents of a village or a voluntary association of residents of several villages into one village community, residents of a settlement, and of a city". According to this Article residents of each of the 28,000 settlements can establish a municipality. There is no clear procedure to do that but during the last years, despite the decreasing population of Ukrainian, the number of local councils increased. At the same time this legal confusion leads to another problem: lack of ubiquity of local self-governance.

We have to stress that the current administrative and territorial division of Ukraine is not well structured. ATUs have a number of enclaves and exclaves, territory of one unit can contain territories of smaller units where local councils are functioning as well. This situation leads to overlapping of functions and competences of different levels of local self-government, misusing of local resources, conflicts etc. Both municipal and district (rayon) levels have huge disproportions in terms of population and territories. For example, the population of the smallest Ukrainian district is around 7 thousand, and that of the biggest district is more than 180 thousand. The same situation exists at municipal level. This causes disproportions in quality of public services that residents of different territorial units of the same level can expect. In addition, the costs of services with lower quality are dramatically higher. Moreover, 92\% of rural territorial communities have populations below 3,000 inhabitants and almost $11 \%$ communities - below 500 inhabitants (Tolkovanov, 2006).

It should also be noted that after "Euromaidan" and Yanukovych's departure in February 2014 decentralisation became a high priority topic on political agenda of the 
new Government and the democratic coalition in the Verkhovna Rada (Parliament of Ukraine). Thus, on 1 April 2014 the Government approved by its Regulation № 333-p a new Concept of the Reform of LSG and of Territorial Organisation of Authority in Ukraine.

This Concept should be realised in two stages. At the first stage (2014) it was planned to create legal framework for voluntary amalgamation of territorial communities with State support foreseen for 5 years and aimed at developing infrastructure and transport accessibility; to regulate the legal framework of the administrative and territorial division (structure); to model administrative-territorial units in regions and to finalise proposals of a new administrative and territorial system; to ensure constitutional basis for the establishment of executive bodies of oblast (region) and rayon (district) councils and to distribute competences of LSG bodies and local State administrations; to organize information and awareness raising campaign about the reform of LSG and territorial organisation of power; to form (in legal terms) LSG bodies on the new territorial basis. These objectives were achieved only partly (creation of the legal framework for the amalgamation of the territorial communities and creation on its basis of 159 new amalgamated communities; adoption in the first reading of the amendments to the Constitution of Ukraine in the part referring to the decentralisation of power, information and public awareness campaign about LSG reform).

At the second stage (2015-2017) it is planned to unify and standardise administrative and social services to be delivered to population by LSG bodies in accordance with the principle of maximum services accessibility, and ensure the legal framework for its adequate funding; to hold local elections based on the reformed system of LSG bodies; to ensure institutional re-organisation of LSG bodies according to the new territorial basis and competences; to improve the system of territorial planning and to provide newly established communities with territorial planning schemes and general plans.

Significant efforts were undertaken by different stakeholders (in particular the President, the Government and the Parliament) to prepare the necessary amendments to the Constitution with regard to the decentralisation of power. On 31 August 2015 the Parliament passed in the first reading, by 265 to 226 majority, the draft law № 2217 on Amendments to the Constitution of Ukraine in Terms of Decentralisation of Power. The draft had been previously seen by the Constitutional Court which ruled on 31 July 2015 that it was consistent with the Constitution of Ukraine and not aimed at liquidation of Ukraine's independence or violation of its territorial integrity. However to change the Constitution at least 300 votes necessary.

According toits explanatorynote, the draftamends certain provisions of the Constitution in terms of administrative and territorial structure. In particular, it reads that the territory of Ukraine is divided into communities, being primary units in the system of administrative and territorial structure of Ukraine. Also, the draft provides for separation of powers in the system of local self-governments and their executive bodies at different levels based on the principle of subsidiarity, which corresponds to the principles of the European Charter of Local Self-Government. It provides for the establishment of local self-government executive bodies within communities, being accountable to community councils. Community chairman presides at council meetings and heads the community local selfgovernment executive body. District councils and regional councils in their turn elect corresponding chairmen from among their members, to head the executive committee.

Material and financial scope of local self-government is introduced. In particular, it is determined that such a scope comprises land, movable and immovable property, natural resources, and other objects being in the communal property of a territorial community; local taxes and fees, some state taxes and other revenues of local budgets. In order to ensure that local authorities comply with the Constitution and laws of Ukraine the institute of prefects is introduced. According to the bill, a prefect is appointed and dismissed by the President of Ukraine upon a submission by the Cabinet of Ministers (Tolkovanov, 2006).

On 17 June 2014 the Parliament adopted the Law № 1508-VII "On Cooperation of the Territorial Communities which determines a legal basis of Intermunicipal Cooperation (IMC), principles, forms, mechanisms of such cooperation, its stimulation, financing and control. This Law determines the cooperation between territorial communities as relations between two or more territorial communities, which are performed on a contract basis in the forms determined by the Law for the purpose of ensuring social, economic and cultural development of the territories, improvement of the quality of services delivering to the population on the basis of common interests and the purposes, effective implementation by LSG bodies of the competences determined by the law. The Law foresees five main forms of IMC (Article 4), i.e.: delegation of one or several tasks to one cooperating entity by other cooperating entities, together with a transfer of appropriate resources; implementation of joint projects, which entails coordination of cooperating entities and accumulation of resources by them for a specified period of time, with the objective of joint implementation of appropriate measures; joint financing of municipal-owned companies, institutions, organisations and infrastructural objects, by the cooperating entities; creation of joint municipal companies, institutions and organisations by cooperating entities; creation of joint management bodies by cooperating entities, for joint execution of the authority determined by law.

According to the information from the Ministry of Regional Development, Construction, Housing and Municipal Economy of Ukraine, by the end of 2015 thirty one IMC projects have already passed the procedure of official registration and were included in the relevant State Register (managed by the Ministry). On 5 February 2015 the Parliament adopted the Law on the 
Voluntary Amalgamation of the Territorial Communities. According to this Law, perspective plans of municipalities' amalgamation were developed and adopted. Despite of sceptical vision that municipalities would not initiate voluntary amalgamation, the process has started quite actively. As a result, 159 merged municipalities representing 794 former hromadas were formed by October 2015. The New LSG bodies of these communities were elected in the last local elections of 25 October 2015.

This relative success of amalgamation and IMC can certainly be attributed to a number of incentives foreseen in the tax and budget codes and other legislation. For example, Article 24-1 of the Budget Code in force since January 2015 completes the provisions on the regional development fund offering additional resources to support economic development projects, which should further convince municipalities that are reluctant to envisage mergers or co-operation. The new legislation also includes measures aimed at sparing the sensitivities of the smallest local authorities and maintaining a fine coverage of the territory through the creation of authorities with 'starosta' status.

Concerning the distribution of the competences, it should be noted that own competences and responsibilities of LSG bodies are fixed by Article 26 of the Law on Local Self-Government dating back to 1997. The system for allocating powers is fairly complex. It makes a distinction between the different organs of authority (council, executive body, mayor) and between its own and delegated powers. The list of competences is quite significant but the Ukrainian legislation does not ensure the principle of subsidiarity: local authorities can execute only those functions prescribed directly by legislation.

In accordance with Article 19 of the Constitutional bodies of state power and bodies of local self-government and their officials are obliged to act only on the grounds, within the limits of authority, and in a manner envisaged by the Constitution and other laws. Article 144 of the Constitution proclaims that the rights of local selfgovernment are protected by judicial procedure. At the same time, the Constitution stipulates that local authorities can address issues of local significance but the definition of the latter or explanation of what is covered by that notion do not exist in the Ukrainian legislation. This situation does not correspond to Article 4 of the European Charter of Local Self-Governance that proclaims the following: "Local authorities shall, within the limits of the law, have full discretion to exercise their initiative with regard to any matter which is not excluded from their competence nor assigned to any other authority" (Tolkovanov, 2011).

It is important to note that the Ukrainian Constitution of 1996 does not define clearly the notion of regional self-government. At the same time, oblasts (regions) and rayons (districts) councils are included in local selfgovernment system; they represent common interests of local (city, village, settlement) communities. There are rayon and oblast councils which, being in theory bodies of local self-government, do not possess any real power neither financially nor organisationally (they do not have their executive bodies responsible to them). As a result, they are totally dependent on the State local administrations. Besides, the oblast and rayon councils can delegate some of their powers to bodies representing the State - local state administrations - in accordance with the Constitution and the national legislation. In this case, local state administrations are accountable to rayon and oblast councils. These arrangements made the system very confusing (Tolkovanov, 2013).

To make the picture even more complex there are some contradictions between provisions of different normative acts regulating LGs activities. In particular, there are contradiction between basic law on Local Self-Government and sectoral legislation, i.e. legislation on land, construction, architecture and other issues. In addition, a number of practical barriers exist limiting the right of local authorities to execute their full responsibility for local development with full discretion, in particular a lack of professional and experienced staff, a weak financial base of local communities and weak capacities of local governments to execute their functions. Also the absence of a clear division of the competences between State authorities and the LSG bodies is observed, which may give rise to overlapping or duplication in the exercise of powers.

From 2012 till the end of 2014 the financial situation of local and regional authorities did not see any serious changes. A number of problems in local finance system of Ukraine were identified by interviewed representatives that are similar to those existing in previous years. The revenues of local budgets were quite significant and represented 7.1\% (2012) and 6.5\% (2014) of GDP (without interbudgetary transfers). But taking into account that GDP per capita in Ukraine is quite low the respective revenues of the local budgets cannot cover the needs of local communities. More than a half of local budgets expenditures (56.4\% in 2014) consist of transfers from the state budget. This dependence of local budgets on state authorities grew during the last several years. However, the local authorities interviewed underlined that these financial resources did not cover all delegated competences of local authorities; around $20 \%$ of public services are underfunded.

The structure of local budgets consists of own taxes and charges, share of state taxes and inter-budgetary transfers. The key role in the structure of local earnings is played by personal income tax that represented more than $60 \%$ of all revenues (without inter-budgetary transfers). At the same time it should be mentioned that rural areas and small communities did not benefit from this tax as it is only gathered in the communities were the taxed persons worked. Thus, only big and developed communities could receive significant share of financial resources from personal income tax. During the 2012-2014 period, the share of own taxes in the revenues of local budget increased very slowly; it is represented only $8 \%$ of revenues of local budgets in 2014 (without inter-budgetary transfers). In 2012 there was an attempt to introduce new property tax as local one though 
it would concerned only a small part of private physical persons property, in addition it was not foreseen that local authorities could influence the share of the tax. The equalisation system was not transparent enough.

The overall situation of local revenues system was characterised by a number of restrictions and limits imposed by the national legislation and the central Government. Local authorities did not have enough competences to regulate and administer even local taxes. The administration of taxes itself was complicated and resource-consuming. Moreover, making use of own resources was problematic for the LSG as these resources were administrated by the central treasury. This situation led to significant delays in payment of local expenditures. At the same time local authorities did not have the right to open bank accounts in private or state banks even for own taxes and charges. Access to capital was limited. Nevertheless, the situation started to change considerably since 2014. By the adoption of the new Budget and Tax Codes in December 2014, a considerable progress has been achieved in the area of financial decentralisation. The key innovations are the following:

- Increasing of financial resources of local authorities through establishment of new local taxes and increasing share of state taxes;

- Property tax is introduced for residential and/or nonresidential property. Local communities have the right to decide on property tax rates and tax relief at their discretion in relation to location (zoning) and other criteria. Tax rate may not exceed $2 \%$ of the minimal wage per square metre (24 UAH per square meter, from December 2015 - 26 UAH). In 2014, local budgets received 45 million UAH from property tax. In 2015, tax revenue is expected to amount to 400 million UAH (around 14 million EUR);

- Local increment for excise tax is introduced for retail companies that trade in excisable goods. The tax is paid into local budgets, where retail outlets selling excisable goods are located. The rate is $5 \%$ of the value of excisable goods (with VAT) starting from 1 January 2015 irrespective of whether local councils adopted relevant decisions, because the Tax Code sets a single rate of 5\%. In 2015 the Ministry of Finance expects local budgets to receive about 8.1 billion UAH of excise tax;

- $60 \%$ of personal income tax will stay in cities of regional significance, districts and merged communities, $15 \%$ - in the regions, and only $25 \%$ will go to the state budget;

- $10 \%$ of profit tax will stay in the regions.

Competences of local authorities to regulate of and administer local taxes were enhanced. For example, local authorities are now authorised to increase/decrease tax rate (property tax), they can open bank accounts in banks (not only in the state treasury) to gather local taxes and charges etc. Land tax has become a local tax, local authorities received the right to regulate its rate, introduce exceptions in the borders of their settlements and beyond.

The equalisation system has changed dramatically. A new formula of horizontal equalisation system based on local revenues has been introduced. Both poor and rich communities receive incentives for development. Poor communities (with revenues below $90 \%$ of country's average) will receive $80 \%$ compensation of the expenditures to cover their needs through subsidies. Communities with revenues from $90 \%$ to $110 \%$ of country's average will not be subject to either compensation or deduction. And communities that earn more than $110 \%$ of country's average will be a subject to deduction of $50 \%$ of the excess. Local budgets planning system has been decentralised: local authorities are now fully responsible for their budget planning instead of having local earnings and expenditures planned by the Ministry of Finance.

Incentives for mergers of local communities were introduced. Merged communities have the same taxes as cities of oblast significance; in addition they will have direct relations with state budgets (instead of rayon budgets). System of state subsides is distributed according to objective criteria. Responsibility of ministries for sectoral development was increased by introduction of sectoral grants for education, healthcare, training of regular labour force and social system.

The principles of formula-based calculation of grants according to introduced sectoral service delivery standards (for services guaranteed by the state) and their financing norms per user were introduced. Though until the list of services is not approved and standards are not developed in social sectors (for example, education, health etc.) the principle cannot be fully implemented. At the same time, for small local authorities, for example villages that do not intend to merge the new tax and budget system is less favourable. But this step was made by the Government to stimulate administrative and territorial reform in the country and introduce incentives for merging. According to the National Reform Council information, as a result of the legal changes in the first half of 2015 local budgets have increased by $37 \%$ in comparison to the same period of 2014. According to information of the analytical centre of the Association of Cities of Ukraine own resources of local budgets increased threefold; the number of subsidized local budgets decreased from $96 \%$ in 2014 to $74 \%$ in 2015 ; the number of local budgets-donors increased from $3.7 \%$ to $15.2 \%$. Also 182 cities received the right to carry out foreign borrowing (previously only 16 cities could do this).

In conjunction with fiscal decentralisation reform, the Government and the Parliament started to implement new basis for regional development policy. Thus, the Law on Principles of Regional Policy № 156-VIII was adopted on 5 February 2015. It defines the main legal, economic, social, environmental, humanitarian and organisational principles of the state regional policy. According to the Law, the state regional policy is determined by a number of strategic documents, i.e.:

- State Strategy for Regional Development of Ukraine which is developed in the long term perspective ( 7 years) and is approved by a decision of the Government;

- Regional development strategies which are prepared 
by the State (oblast and rayon) administrations for the duration of the state strategy of regional development. These documents should define objectives, priorities and main problems of socio-economic development of the respective regions as well as stages and mechanisms of their implementation; monitoring and evaluation system implementation;

- Action Plan on the Implementation of the State Strategy of Regional Development of Ukraine as well as actions plans for the realisation of the regional strategies.

Among other important decisions on regional development, we have to stress the following documents: Resolution № 195 of the Cabinet of Ministers of Ukraine "Using Resources of the State Regional Development Fund in 2015" of 18 March 2015; and Resolution № 196 of the Cabinet of Ministers of Ukraine "Certain Issues of the State Fund of Regional Development for 2016" of 18 March 2015.

It is important to note that the Ministry of Regional Development, Construction, Housing and Municipal Economy of Ukraine as the key authority for the implementation of the decentralisation reform demonstrates strong will to introduce project-based approach concerning the financing of regional projects in connection with the approved regional strategies and development priorities of the respective territories. The possibility to interfere in the distribution of funds by the Government is totally limited; there is no possibility to distribute funds among regions voluntarily [8]. In addition, some schemes were introduced that is devoted to invest more funds to under-developed regions. The Government decided to use the Fund to support merged communities as well as further realisation of IMC projects. In 2015 the Fund amounts to 3 billion UAH; it is planned that in 2016 it will amount to 4.7 billion UAH.

That status of local civil servants is regulated by the Law on Service in LSG Bodies of 2001 and is in principle similar to the general civil service, while taking into account some specific features and the structure of local self-governance bodies. In both cases public service is a professional activity that should be conducted without political interference. The numbers of civil servants of LSG bodies are determined by the apparatus of the relevant council and its executive bodies. All other workers of public sector, including education, health sectors, police etc. are not a part of the service of local self-governance bodies. The total number of servants of local self-governance bodies in 2014 was 84,548 (without information on AR Crimea, city of Sevastopol and occupied territories of Luhansk and Donetsk oblasts). At the same time the total number of the State civil servants amounts to 295,709 (Civil Service in Figures, 2015). During the last years the number of servants has slightly decreased. In accordance with the Figure 16, women working in the State civil service and the service in LSG bodies (red colour) represented in $201475 \%$ (285 243 persons) of the total number (380257) of the civil servants (green colour), and men (blue colour) - only 25\% (95 014 persons). The Constitution of Ukraine (Article 38) recognises equal rights of all citizens to join the state and local self-government civil service. At the same time, as the Figure 16 shows, more than $75 \%$ of total numbers of servants in local self-governance bodies are women.

The Law on Service in LSG Bodies regulates legal, financial and social conditions of the holders of not elected positions in local self-government bodies (procedure of appointment, ranks and categories, general salary and retirement conditions). It also stipulates the scope of authority for the officials oflocal self-governments and legal protection during the service in local self-governments. However, there is no sufficient control mechanism over local self-governments to check the local normative act concerning civil service for compliance with the Law on Service in LSG Bodies.

The procedure of selection and appointment of servants in local self-governance bodies are based on an open competition. However, this procedure is quite complicated and lengthy especially taking into account anticorruption requirements and checks before appointment of selected public servant. Because of that combined with low prestige of public service and uncompetitive conditions the number applicants is very limited. At the same time there are cases of corruption and abuse of power in the process of recruitment. In 2014 only $57 \%$ of local servants were recruited on the basis of competition. Promotions through unjustified managerial decisions and under political pressure are not uncommon. As a consequence, the proportion of management staff is already too high (26\% in 2014) vis-à-vis the number of specialists (74\%) at central and local bodies of state executive power. In local self-government the proportion is even higher ( $42 \%$ to $58 \%$ in 2012 ).

According to the relevant programmes that are financed mostly from the state budget but also partly from local budgets public servants have to increase their competence through the national training system (Modern Leadership for Modern Government). The system is coordinated by the National Agency on Civil Service as well as the National Academy of Public Administration under the President of Ukraine. Public servants can increase their competence only in state-owned institutions. In 2014 around 8,000 local civil servants participated in such training.

All these and other problems require a modernisation of the national legislation on public civil service (State civil service and service in LSG bodies). In this regard, the Parliament approved in November 2015 the new Law on Civil Service, which aims at improving the functioning of the State administration, but is also expected to have positive impact on the service in LSG bodies. According to this Law, top civil service appointments will no longer be divided between political parties under a quota system, but will be made via transparent competition - a special commission will first vet candidates before the Cabinet makes the final decision. The commission will consist of social activists, along with representatives of the Parliament, the President, the Government, the head of the National Anti-Corruption Bureau, and members of trade 
unions. The law is also expected to help depoliticise the civil service - there will be a difference between political and administrative positions. This Law was entered into force on 1 May 2016 and the respective amendments to the Law on Service in LSG Bodies should be adopted by the Parliament of Ukraine this year.

\section{Conclusions and recommendations}

After several years of "stagnation" the current Ukrainian Government re-started the process of improving the local democracyand the functioning of self-governments. On 1 April 2014 the Government of Ukraine approved (by its Regulation № 333-p) the new concept of the reform of LSG and territorial organisation of the authorities in Ukraine. Significant efforts are connected with changes to the Constitution in regard of decentralisation. The proposed changes passed the first reading in the Parliament in August 2015.

At the same time, the Parliament of Ukraine adopted in June 2014 the Law on Inter-municipal Cooperation and in February 2015 - the Law on Voluntary Merger of the Territorial Communities (hromadas). The process of voluntary merges was promoted by very strong financial incentives (close to cancelling of all transfers to very small municipalities, if they do not decide to merge). In such environment the voluntary amalgamation process started quite actively. As a result 159 merged municipalities representing 794 cities, settlement and village councils participated in municipal elections in October 2015. Changes implemented since the end of 2014 also mean that most of competences that were transferred to central government in the past, now returned or are in the process of returning to the LSG level. There is an intention to transfer some other functions of the central government to municipalities, for example in the area of construction permits.

In the end of 2015 the Parliament of Ukraine adopted the new Law on Civil Service which was entered into force on 1st May 2016. This law will influence the functioning of the central government level, but is expected to have positive impact also on local level. This law is also expected to help depoliticise the civil service - there will be a difference between political and administrative positions.

Important changes are connected also with fiscal decentralisation - described in details in the following part. With this the most important unaddressed legislative issue is the situation on district and regional level - there exist elected district and regional councils which, being in theory bodies of local self-government, do not possess any real power neither financially nor organisationally (they do not have any executive bodies responsible for them). Ukraine, between 2012 and the end of 2014 did not carry out serious changes that would improve the financial situation of local and regional authorities. However, in the end of 2014 massive changes started, especially when the Parliament adopted amendments to the Budget and Tax Codes. The key innovations are as follows: increasing financial resources of local authorities through the introduction of new local taxes and increasing their share in some state taxes; providing local authorities with significantly enhanced freedom in regulation and administration of local taxes and their administration; modernisation of the equalisation system has been changed dramatically by the introduction of a new formula of horizontal equalisation system based on local revenues; decentralisation of the local budgets planning system; creation of the legal basis for amalgamation of the local communities; distribution of the state subsides according to the objective criteria; introducing the principles of formula-based calculation of grants according to introduced sectoral service delivery standards (for services guaranteed by the state) and their financing norms per user etc.

At the same time, it will be recommended to Ukrainian authorities to reinforce their efforts on further LSG development as an integrated part of wider public administration reform in order to pay a particular attention to the following objectives:

- A completion of the constitutional reform in its part relating to the decentralisation of power should be treated as a priority objective: 2 . Territorial boundaries of local selfgovernance bodies and executive power should be defined in order to reinforce the three-tier system of administrative and territorial structure (with 27 regions, 120-150 rayons, 1500-1800 local communities);

- A clear division of competences should be set between the local self-governance bodies of different levels (hromada, rayon and oblast). At the same time, the competences which are the most vital for peoples' life should be transferred to the levels closest to the people following the principle of subsidiarity;

- A clear division of competences should be set between the LSG bodies and local state administration bodies. The latter should transfer most of their competences to local self-governance bodies and retain only control functions; - The fiscal decentralisation reform should be continued with a particular focus on the implementing each of the recommendations formulated by the EaP CSF Sub-group for Local Government and PAR in 2012;

- The accountability of LSG bodies to the citizens of the respective hromadas should be reinforced. People will become aware that the quality of the local power operation will depend on their voting. So the quality of life will depend on the residents themselves;

- Standards for services delivery and its financing should be developed with particular focus on education, health, and other social services. Full implementation of these standards into the state transfers/subsidies mechanisms will ensure consistent access to public services throughout the whole territory of Ukraine. This step will stimulate optimisation of social infrastructure, spending resources for increasing quality of services instead of maintenance of public utilities;

- A more transparent framework for local budgets should be established. Increasing of local funds should be accompanied by enhancing mechanism of public control 
and supervision over utilisation of these funds. Local authorities have to be accountable to local communities especially in terms of planning, implementation and reporting on spending of local finances;

- Awareness of the citizens of the decentralisation reform, its objectives and the main results should be enhanced and promoted;

- Further development of IMC as an important stage for further amalgamation of the communities (hromadas) should be continued. At the same time, the process of amalgamation of the communities should be further supported by the central government. In this regard, the dialogue with the newly elected mayors and local elected representatives should be reinforced; awareness raising campaigns among mayors based on success-stories and peer-to-peer approach may be also used;

- The autonomy of LSG bodies to manage their own human resources within the framework provided by the relevant laws should be further guaranteed. At the same time, proper control mechanisms of compliance with the provisions of law should be established. The new Law on Service in LSG Bodies should be finalised and adopted. Its quick implementation should be a priority for further realisation of the decentralisation reform in Ukraine;

- The delegated powers and competences should be fully financed by the central government, introduction of new privileges and bonuses should be accompanied by respective financial resources to the local budgets.

\section{References}

Civil Service in Figures (2015). National Agency on Civil Service of Ukraine, Kyiv, retrieved from: www.nads.gov.ua Council ofEurope. Additional Protocol to the European Charter ofLocal Self-Government on the Right to Participate in the Affairs of L LocalAuthority,2009, retrieved from: https://rm.coe.int/CoERMPublicCommonSearchServices/ DisplayDCTMContent?documentId $=090000168008482 \mathrm{a}$

European Charter of Local Self-Government: Standing Conference of Local and Regional Authorities, Strasbourg, 1985. Encyclopedia of Public Administration in 8 tomes (2011). Group of authors headed by Y. Kovbasiuk. Kyiv, National Academy of Public Administration under the President of Ukraine. Tom 6 «Civil Service», 524 p.

European Handbook on the Implementation of the Model Initiatives Package on Public Ethics at Local and Regional Levels. Council of Europe, Strasbourg, 2006, 80 p.

Kuybida, V., Tkachuk, A., Tolkovanov, V. (2010). Experience on the implementation of good governance standards on local level in Ukraine and other European countries, Kyiv, "Kramar", 317 p.

Modern Leadership for Modern Government. Council of Europe Centre of Expertise for Local Self-Government Reform, Strasbourg, 2013, retrieved from: https://wcd.coe.int/com.instranet.InstraServlet? command=com. instranet.CmdBlobGet\&InstranetImage $=2751082 \&$ SecMode $=1 \&$ DocId $=1991708 \&$ Usage $=2$

Public Ethics Benchmark. Council of Europe Centre of Expertise for Local Self-Government Reform, Strasbourg, 2009, retrieved from: https://wcd.coe.int/com.instranet.InstraServlet?command=com.instranet. CmdBlobGet $\&$ InstranetImage $=2564758 \&$ SecMode $=1 \&$ DocId $=1910774 \&$ Usage $=2$

Tolkovanov, V. (2006). "La mise en oeuvre du nouveau systeme de l'autonomie locale en Ukraine”. These de doctorat (droit public), Universite Robert Schuman de Strasbourg III, 405 p.

Tolkovanov, V. (2011). Public Administration Reform in Ukraine: main objectives, current status and problems to be solved. Public Policy and Economic Development: scientific journal. - Mykolaiv, № 2, p. 5-12.

Tolkovanov, V. (2013). Tools for Ensuring Good Governance at Local and Regional Levels. PhD Thesis in Public Administration. - Zaporizhia, $436 \mathrm{p}$.

Toolkit on Local Government Capacity-Building Programmes. Council of Europe, Strasbourg, 2011, retrieved from: https://wcd.coe.int/com.instranet.InstraServlet?command=com.instranet.CmdBlobGet\&InstranetImage= 2565163\&SecMode $=1 \&$ DocId $=1910750 \&$ Usage $=2$

\section{Денис ЗАПИСНОЙ}

\section{ДЕЦЕНТРАЛИЗАЦИЯ И РАЗВИТИЕ ОРГАНОВ МЕСТНОГО САМОУПРАВЛЕНИЯ КАК КЛЮЧЕВЫЕ ВОПРОСЫ РЕФОРМИРОВАНИЯ ГОСУДАРСТВЕННОГО УПРАВЛЕНИЯ В УКРАИНЕ: ТЕКУЩЕЕ СОСТОЯНИЕ И НОВЫЕ ЦЕЛИ}

Аннотация. В статье представлены статус и основные цели децентрализационных процессов, а также развитие органов местного самоуправления в Украине. Децентрализация анализируется в качестве интегрированного элемента более масштабных реформ государственного управления. Эффективное государственное управление является необходимым для демократического управления. Оно также непосредственно влияет на способность правительства предоставлять общественные (административные и коммунальные) услуги и стимулировать конкурентоспособность и рост. Общественная административная реформа должна привести к улучшенной прозрачности, ответственности и эффективности, а также обеспечить большее внимание потребностям граждан и бизнеса. На основе анализа украинского законодательства выделены лучшие национальные и международные практики, предложения и рекомендации относительно возможных способов дальнейшего развития органов местного самоуправления, в частности в рамках проведения политики интеграции с ЕС. 